European journal of American studies

1-1 | 2006

Spring 2006

\title{
American Studies in Turkey
}

Gülriz Buken

\section{(2) OpenEdition}

\section{Journals}

Electronic version

URL: https://journals.openedition.org/ejas/1044

DOI: 10.4000/ejas. 1044

ISSN: 1991-9336

\section{Publisher}

European Association for American Studies

\section{Electronic reference}

Gülriz Buken, "American Studies in Turkey", European journal of American studies [Online], 1-1 | 2006, document 20, Online since 16 January 2006, connection on 09 July 2021. URL: http:// journals.openedition.org/ejas/1044 ; DOl: https://doi.org/10.4000/ejas.1044

This text was automatically generated on 9 July 2021.

Creative Commons License 


\title{
American Studies in Turkey
}

\author{
Gülriz Buken
}

1 In the discipline of American Studies in Turkey, the major contribution emanates, on the one hand, from the American Culture and Literature Departments instituted in various Universities in Turkey and, on the other, from the American Studies Association of Turkey. Up till now, unfortunately, no Research and Performance Institute or Center for the Study of America has yet been established to secure the necessary contacts with other similar institutions in Europe and in the United States, to facilitate research and international collaboration for academic activities and publications. Nevertheless the attempts to establish such a Center in Istanbul have been initiated and it is hoped they will bear fruit within a year.

2 Initially the English Language and Literature Departments, where most of the current faculty in American Culture and Literature Departments have been educated, trained and taught the courses related to American culture and literature, constituted an insignificant fraction of the total courses in the various curricula. When the latter were founded by permission of the Council of Higher education for the first time in 1982 at Hacettepe University, inevitably, given the lack of faculty trained in the field with degrees from US Universities with American Studies Programs and/or Departments, the courses related to American Studies in the curricula of the originally founded American Culture and Literature Departments did not exceed more than half of the total courses offered. Only when these Departments started to offer MA and PhD programs and, in due time, granted degrees, did the number of trained faculty exceed the original five American Literature specialists. Those who could get the few Fulbright scholarships were exposed to American culture and the American education system and were able to earn their $\mathrm{PhD}$ degrees at American Universities; the rest had to train themselves with short visits, often privately funded, during which they could do research for their dissertation. The faculty then was and nowadays is enhanced by Fulbright visiting Professors.

3 Attending Conferences and giving papers in Europe or in the United States always remained a dream as there existed no funds for that purpose available in State Universities for Teaching and Research assistants, let alone graduate students. Those 
who could attend the Salzburg Seminars or few other conferences were financially supported by their families. Fortunately, in recent years, the younger academics-to-be in state Universities are luckier in this respect and various other funds are available for them, such as the Erasmus Program and an increased number of Fulbright degree scholarships. When the private Universities came on the scene, the latest being Halic University in 1998, those enrolled in the graduate programs of American Culture and Literature or the History Department-Bilkent University is unique in this regard as it grants MA and PhD degrees in American History- were and are subsidized if they participate and give papers at Conferences taking place in Turkey or abroad. Only recently the American Studies Association of Turkey has also been awarding travel grants for graduate students who have papers accepted for Conferences held in the United States and both graduate and undergraduate students who attend the annual American Studies Conference in Turkey. At Baskent University, the Department organizes the International Students' Seminar which is a unique venue where the students have an opportunity to touch base and exchange ideas with graduate students from other countries in Europe.

4 As can be deduced, both receiving the required training in the discipline and trying to publish in citation indexed journals in the US-now a requirement for the PhD Degreeis an extremely demanding and highly competitive mission to be accomplished with limited means.

5 However, the American Culture and Literature Departments aim at addressing a broad spectrum of American Studies at large-American literature, history, philosophy, religion, arts, politics and social life, how American literary and cultural traditions have developed and were subject to transformations in the course of history; their curriculum is based on courses dealing with the survey of different genres and/or different centuries in American Literature. Moreover, they are geared for training the students for comparative analysis as expressed openly by the mission statement of a department: "The department offers a course selection that examines the United States in all its complexity, integrating literature, culture, and history. This interdisciplinary program will not only introduce students to the study of the United States, but will also develop critical and creative thinking skills that will enable students to reflect upon their own culture and its history and literature." Likewise, the mission of the Department at Ege University is "In an age of globalization,[...] to offer a wide choice of courses providing insight into both the American and the international agenda. The result of this curriculum is to encourage a comparative perspective on the world." None of the mission statements of other Departments deal specifically with American Studies either. Accordingly, a majority of courses, in their curriculum, are not related to different fields within American Studies (besides literature) except for the Introduction to American Studies I and II \& American Studies in a Global Context and other restricted electives directly related to American Studies offered at Bilkent University, and American Studies specific courses offered at Ege University (for example American History I \& II, History of Turkish-American Relations, US Government And Politics, American Popular Culture, American Intellectual History \& Criticism, American Themes And Issues, History of American Economy, Aspects of American Culture, Cultural Regions of the US.)

6 Naturally enough, the dissertations prepared for degrees granted by the Departments in Universities other than Ege and Dokuz Eylul, both in Izmir, without exception focus on the analysis of literary works. The latter specific cases are also reflected by the focal 
points of MA and PhD. dissertations, bearing such titles as The Influence of the Roosevelt New Deals upon Contemporary US Culture (2001); A Comparative Approach to American and Balkan Political Cultures from a Romanian perspective (2003); The Example of US Influence upon the Central Asian States after the Soviet Disintegration(2002); Efforts of the United States to become a World Power During the Interwar Period and the Effects of its Near-Eastern Policy Upon Turkey (1997); Turkish-American Relations Concerning the Cyprus Question (1996); Realpolitik or Idealism? US Policy on the Baku-Ceyhan Pipeline: A Case Study (2002); Power and Ideology in American Political Texts: A Critical Discourse Analysis (2001); Turkish-American Cultural Relations: The Reflections of America and Turkish-American Relations in Political Humor Magazines published in Turkey between 1945 and 1960 (1999); The Interaction of American Painting and Poetry through Urbanization between 1900 and 1940 (2001); Debates on Society, Individual and Death and their Reflections on American Popular Culture in the1990's (2003); Twentieth-Century American Foreign Policy and Turkish-American Relations after the Second World War (1998); Turkish-American Cultural Relations and its Reflection on Political Cartoons [1960-1980] (2005).

7 The American Studies Association of Turkey, on the other hand, contributes to the development of American Studies in Turkey by organizing monthly lectures, panels and the annual conferences which, in recent years, have become international. In these conferences, initiated in 1977, a broad spectrum of themes have been covered ranging from "The American South," "The American West", "The Worlds Women Make," "Media, Culture and Nation in the Age of Information" "Postmodernism," "Multiculturalism in America," and "Challenging America: Similitude and Difference" to "Theory, Themes and Practice in American Studies in Turkey."

8 At the $30^{\text {th }}$ Annual Conference on "American Studies: Past, Present and Future", as Prof. Clifford Endres pointed out in his Opening Remarks "[i]t was felt that, after 30 years, the time had arrived to take a fresh look at the position of American studies in the Turkish academic establishment; to examine what's gone right over the last three decades and to see what could do with a bit of tweaking. In short, if we can see where we've come from, we may be able better to see where we're going. This will entail looking at the state of American studies in Turkey-its pedagogy, its curricula, its research and publication possibilities, and, perhaps most importantly, its usefulness to students-and seeing where they might be improved". The roundtables on "Curriculum and Research Issues in Turkey," and "American Studies from the European Point of View" and the panels on "Definitions and Re-definitions," "Historical Reflections," "Methodological Challenges," "Pedagogical Perspectives," and "Chicana and Chicano Studies," all provided different perspectives on American Studies in terms of teaching, researching and publishing in the discipline in domestic and international spheres. Moreover, it was a unique training process for the student participants and collaborators.

Obviously, realities cannot be surmounted in a short time but since the potential for the flourishing of the discipline of American Studies in Turkey rests in the young generation of Americanists, in due time, Turkish scholars will also make effective contributions in the international arena, "mediating between transnational and nationalist perspectives." 


\section{AUTHOR}

GÜLRIZ BUKEN

Bilkent University, Ankara 